\title{
Proposal for structural testing of double root low capacity wind turbine blades based on the Iec 61400-2 Standard
}

\section{Propuesta de ensayos estructurales de aspas de turbina de viento de baja capacidad de doble raíz con base a la Norma IEC 61400-2}

SANTIBAÑEZ-MALDONADO, Adrian†*, LÓPEZ-GARZA, Víctor, SORIANO-PEÑA, Juan Felipe and MARIN-TELLEZ, Paulina

Universidad Michoacana de San Nicolas de Hidalgo, Facultad de Ingeniería Mecánica

ID $1^{\text {st }}$ Author: Adrian, Santibañez-Maldonado / ORC ID: 0000-0003-2090-9556, Researcher ID Thomson: AAF-76252021, CVU CONACYT ID: 1009460

ID $1^{\text {st }}$ Co-author: Víctor, López-Garza / ORC ID: 0000-0001-9090-9119, Researcher ID Thomson: H-6969-2018, CVU CONACYT ID: 554311

ID $2^{\text {nd }}$ Co-author: Juan Felipe, Soriano-Peña / ORC ID: 0000-0003-1370-2274, CVU CONACYT ID: 233426

ID $3^{\text {rd }}$ Co-author: Paulina, Marin-Tellez, / ORC ID: 0000-0003-2966-3409, Researcher ID Thomson: G-2113-2019, CVU CONACYT ID: 928539

\begin{abstract}
In this article, the results of the numerical simulation are shown, as well as the results of the structural tests using extensometry, for a low capacity double root wind turbine blade based on the IEC 61400-2 standard. A methodology was developed to carry out the experimental plan. The results obtained by means of numerical simulation were compared with those obtained by extensometry, concluding that the blade will work safely already in operation because the values obtained from microdeformations are far from the blade failure limit.
\end{abstract}

Blade, Tests, Simulation

\section{Resumen}

En el presente artículo, se muestran los resultados de la simulación numérica, así como también los resultados de los ensayos estructurales mediante extensometría, para un aspa de turbina de viento de doble raíz de baja capacidad en base a la norma IEC 61400-2. Se desarrolló una metodología para llevar a cabo el plan experimental. Se compararon los resultados obtenidos mediante la simulación numérica con los obtenidos mediante extensometría, concluyendo que el álabe trabajará seguro ya en funcionamiento debido a que los valores obtenidos de microdeformaciones están lejos del límite de fallo del álabe.

Álabe, Ensayos, Simulación

Citation: SANTIBAÑEZ-MALDONADO, Adrian, LÓPEZ-GARZA, Víctor, SORIANO-PEÑA, Juan Felipe and MARINTELLEZ, Paulina. Proposal for structural testing of double root low capacity wind turbine blades based on the Iec 61400-2 Standard. Journal Innovative Design. 2021, 5-12: 1-9

\footnotetext{
*Correspondence to the Author (e-mail: jose.colin@ ciateq.mx)

$\dagger$ Researcher contributing as first author.
} 


\section{Introduction}

The production of electrical energy is a very important factor in the industrial and technological development of a country. Increasingly, energy production processes seek to be cleaner and with fewer greenhouse gas emissions. Renewable energies arise from this need to generate energy with less adverse effects on the planet. Among renewable energies, hydroelectric, solar and wind power stand out for their production.

Wind energy is produced by harnessing wind currents to move a generator through the blades of wind turbines. The blades are the main components of wind turbines, hence their importance in design and manufacture.

The structural integrity of the blades is of paramount importance because, if any blade fails, the turbine will no longer function properly. As a result of this problem, quality standards have arisen which propose a methodology of static and fatigue tests to ensure the service life of the blades and all the turbine components.

IEC 61400-2 is the standard par excellence for low power turbines, which classifies them as turbines delivering less than $50 \mathrm{KW}$.

This paper shows the evaluation of a double root blade of a $2400 \mathrm{~W}$ wind turbine, according to the load hypotheses of the IEC 61400-2 standard. The results of the numerical simulation and also the results obtained by means of extensometry are shown.

\section{Load hypotheses to be applied based on the IEC 61400-2 standard}

The standard specifies the methodology of simplified loads, as well as the modelling of AP (Small Wind Turbines) blades, in order to guarantee their quality and good operation. The load hypotheses that were evaluated are: normal operation, maximum rotor speed and extreme wind load, which are shown in table 1 . For each design state, the appropriate type of analysis by "F" and by " $\mathrm{U}$ " is given. F refers to the fatigue load analysis, to be used in the fatigue stress assessment.
$\mathrm{U}$ refers to the analysis of critical loads such as the analysis of the maximum excess strength of the material, the analysis of the extreme deformation and the analysis of the stability.

\begin{tabular}{|c|c|c|c|}
\hline Design situation & $\begin{array}{c}\text { Load } \\
\text { assumptions }\end{array}$ & Type of analysis & $\begin{array}{c}\text { Design } \\
\text { situation }\end{array}$ \\
\hline \multirow[t]{4}{*}{ Energy production } & $\mathbf{A}$ & Normal operation & $\mathrm{F}$ \\
\hline & B & Orientation & $\mathrm{U}$ \\
\hline & $\mathrm{C}$ & Orientation error & $\mathrm{U}$ \\
\hline & D & Maximum thrust & $\mathrm{U}$ \\
\hline \multirow{2}{*}{$\begin{array}{l}\text { Producción de } \\
\text { energía de más } \\
\text { ocurrencia de fallo }\end{array}$} & $\mathbf{E}$ & $\begin{array}{ll}\text { Velocidad } & \mathrm{de} \\
\text { rotación máxima } & \end{array}$ & $\mathrm{U}$ \\
\hline & $\mathbf{F}$ & $\begin{array}{l}\text { Cortocircuito en la } \\
\text { conexión de carga }\end{array}$ & $\mathrm{U}$ \\
\hline Parada & G & $\begin{array}{l}\text { Desconexión } \\
\text { (frenado) }\end{array}$ & $\mathrm{U}$ \\
\hline $\begin{array}{ll}\text { Carga extrema de } \\
\text { viento }\end{array}$ & $\mathbf{H}$ & $\begin{array}{lll}\text { Carga } & \text { extrema del } \\
\text { viento } & & \\
\end{array}$ & $\mathrm{U}$ \\
\hline $\begin{array}{l}\text { Condiciones de } \\
\text { inmovilización y de } \\
\text { falta }\end{array}$ & I & $\begin{array}{l}\text { Inmovilización con } \\
\text { carga del viento y } \\
\text { exposición máxima }\end{array}$ & $\mathrm{U}$ \\
\hline $\begin{array}{l}\text { Transporte, } \\
\text { montaje, } \\
\text { mantenimiento } \\
\text { reparación }\end{array}$ & $\mathbf{J}$ & $\begin{array}{lrr}\text { Deberá } & \text { estar } \\
\text { indicado } & \text { por } & \text { el } \\
\text { fabricante } & & \end{array}$ & $\mathrm{U}$ \\
\hline
\end{tabular}

Table 1 Design load assumptions for the simplified load calculation method.

Source: IEC 61400-2 (2015).

Calculation of the loads to be applied to the blade

\section{Scenario A: normal operation}

The design load for "normal operation" is a fatigue load. The loading assumption assumes a constant range fatigue load for the blade.

$$
\begin{aligned}
& \Delta F_{z B}=2 m_{B} R_{\operatorname{cog}} \Omega_{n, \text { design }}^{2} \\
& \Delta M_{x B}=\frac{Q_{\text {design }}}{B}+2 \mathrm{~m}_{\mathrm{B}} \mathrm{gR}_{\mathrm{cog}} \\
& \Delta M_{y B}=\frac{\lambda_{\text {design }} Q_{\text {design }}}{B}
\end{aligned}
$$

Scenario E: maximum rotor speed

The load due to centrifugal force at the blade root FzB is calculated as follows:

$F_{z B}=m_{B} R_{c o g} \Omega_{n, m a ́ x}^{2}$

Scenario H: extreme wind load

In this load scenario, the wind turbine operates as designed for extreme wind speeds. The loads are to be calculated by taking the maximum wind speed recorded over the last 50 years, $\mathrm{V}_{\mathrm{e} 50 \text { : }}$ 


$$
M_{y B}=\frac{C_{D}}{4} \rho V_{e 50}^{2} A_{\text {projB }} R
$$

The values obtained are shown in table 2 .

\begin{tabular}{|l|l|l|}
\hline \multicolumn{2}{|c}{ Load assumptions } & \multicolumn{2}{c|}{ Value } \\
\hline \multirow{2}{*}{ A } & Normal operation & $\Delta \mathrm{F}_{\mathrm{zB}}=12151.12 \mathrm{~N}$ \\
\cline { 3 - 3 } & & $\Delta \mathrm{M}_{\mathrm{xB}}=1666.57 \mathrm{Nm}$ \\
\cline { 3 - 4 } & & $\Delta \mathrm{M}_{\mathrm{yB}}=378.67 \mathrm{Nm}$ \\
\hline $\mathbf{E}$ & Maximum rotational speed & $\mathrm{F}_{\mathrm{zB}}=62125 \mathrm{~N}$ \\
\hline $\mathbf{H}$ & Extreme wind load & $\mathrm{M}_{\mathrm{yB}}=2970.34 \mathrm{Nm}$ \\
\hline
\end{tabular}

Table 2 Values obtained for each load scenario Source: Own Elaboration

\section{Methodology}

Figure 1 shows in detail the stages of the experimental plan. The first is to identify all the non-experimental factors or variables that may affect the experiment and determine how to control them; such as environmental factors, temperature, noise, etc. In order to carry out the structural tests on the blades, the static and fatigue load test bench (figure 2) designed by Erick Pérez Juárez will be used, which is made up of the following parts:

$\begin{array}{ll}\text { 1. } & \text { Base } \\ \text { 2. } & \text { Head - support } \\ \text { 3. } & \text { Head - clamp } \\ \text { 4. } & \text { Blade } \\ \text { 5. } & \text { Force system }\end{array}$

Identify all factors that may affect the experiment.

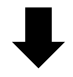

Selecting the methodology experimental

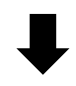

Selecting a representative sample

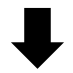

Select instruments

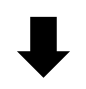

Develop procedures for data collection

State the null hypothesis

Figure 1 Methodology of the pilot scheme

Source: Monje, C. (2011). Metodología de la investigación cuantitativa y cualitativa guía didáctica, Neiva, Colombia: Universidad Surcolombiana

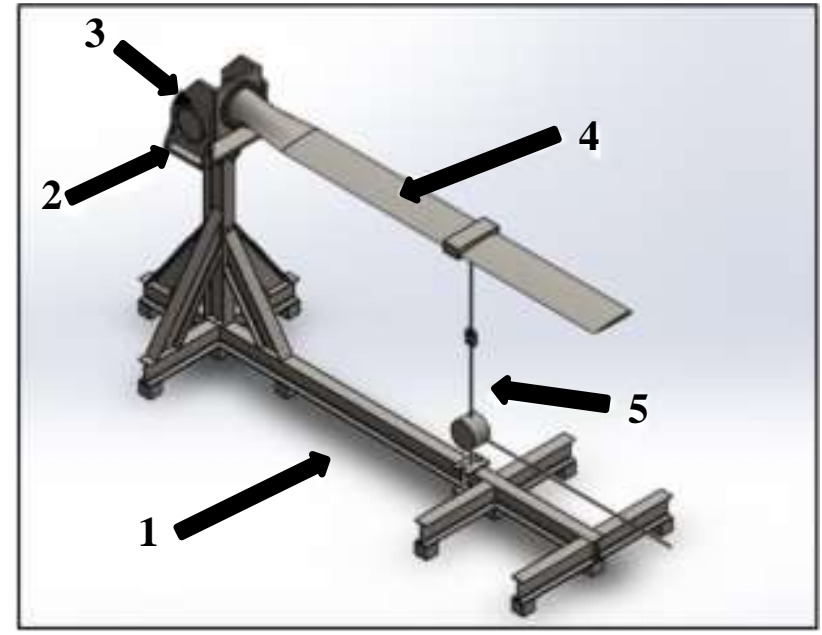

Figure 2 Static and fatigue test bench

Source: Erick Pérez Juárez. Construction of a fatigue testing machine for low-capacity wind turbine blades. UMSNH, 2019

\section{Simulation of load assumptions on the double-root blade}

The blade was modelled using CAD software and divided into 25 sections as shown in figure 3. A NACA 4412 profile was used for the modelling of the main root and the double root.

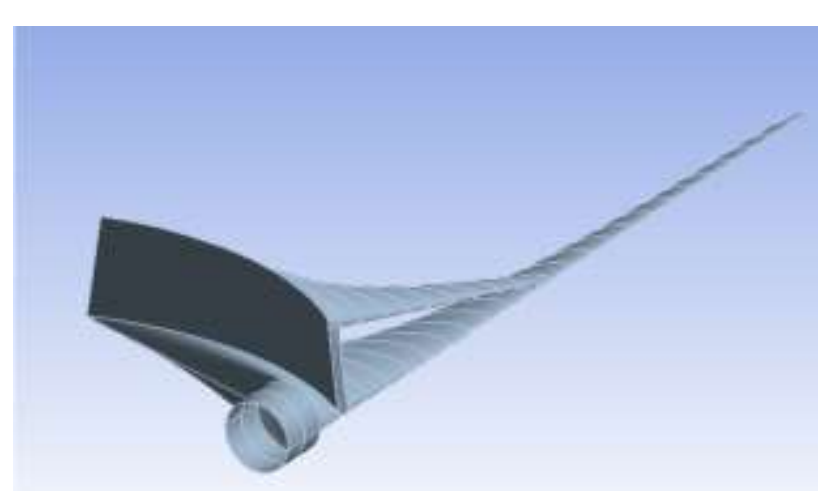

Figure 3 Blade modelling in CAD software Source: Own Elaboration

The blade is made of several layers of composite material, glass fibre/epoxy, arranged at $45^{\circ}$ and $90^{\circ}$ as shown in figure 4 . 


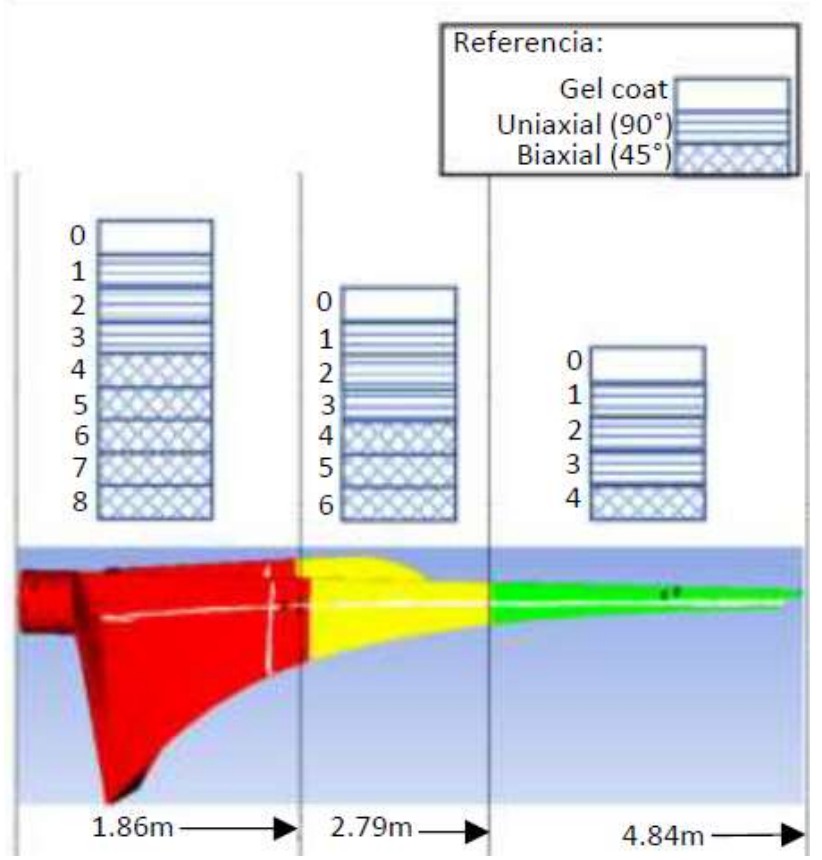

Figure 4 Distribution of fibreglass/epoxy sheets on double-rooted blades

Source: Own Elaboration

The root zone (in red) is defined by nine layers including the gel coat layer, the middle zone (in yellow) is defined by seven layers including the gel coat layer, and finally the tip zone (in green) is defined by five layers including the gel coat layer.

\section{Meshing and boundary conditions}

The meshing was done with the help of finite element software using triangular elements. The quality of the meshing is shown in table 3 .

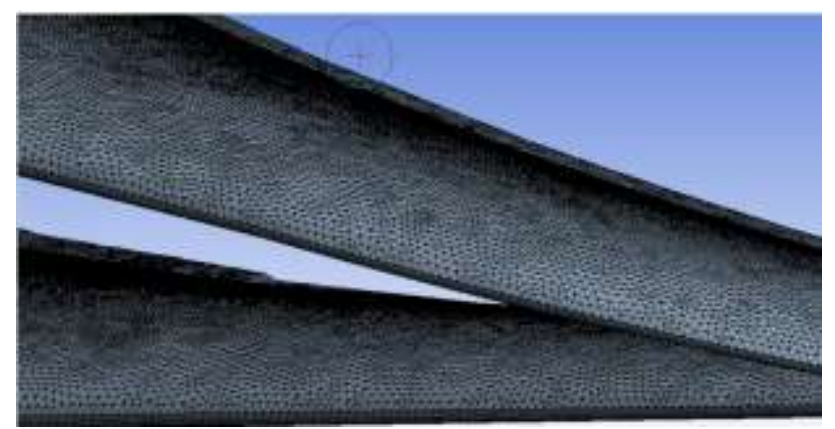

Figure 5 Blade grid, triangular elements Source: Own Elaboration

\begin{tabular}{|l|r|}
\hline Nodes & 267276 \\
Elements & 534311 \\
Mesh Metric & Promedio \\
\cline { 2 - 2 } Element Quality & 0.967326688775866 \\
Aspect ratio & 1.1893 \\
Skew & 0.050672 \\
\hline Parallel skew & 0 \\
\hline
\end{tabular}

Table 3 Meshing metric

Source: Own Elaboration

ECORFAN ${ }^{\circledR}$ All rights reserved
The boundary conditions will consist of applying the load assumptions by adding an embedment condition at the root of the blade. For practical purposes, the loading assumptions involving moments on the blade will be transformed to forces on the same axis, using the distance to the root which in this case is 3.25 metres. A summary of the boundary conditions for the 3 load scenarios is presented in table 4.

\begin{tabular}{|l|l|l|l|}
$\begin{array}{c}\text { Load } \\
\text { assumptions }\end{array}$ & $\begin{array}{l}\text { Moment at } \\
\text { x (flapwise } \\
\text { moment) } \\
\text { N }\end{array}$ & $\begin{array}{c}\text { Moment at } \\
\text { y } \\
\text { (edgewise } \\
\text { moment) } \\
\text { N }\end{array}$ & \multicolumn{1}{c|}{$\begin{array}{c}\text { Z-force } \\
\text { (centrifugal) }\end{array}$} \\
\hline $\mathbf{A}$ & 256 & 115 & 12151.12 \\
\hline $\mathbf{E}$ & $\begin{array}{l}\text { Not } \\
\text { applicable }\end{array}$ & $\begin{array}{l}\text { Not } \\
\text { applicable }\end{array}$ & 62125 \\
\hline $\mathbf{H}$ & $\begin{array}{l}\text { Not } \\
\text { applicable }\end{array}$ & 459.1 & $\begin{array}{l}\text { Not } \\
\text { applicable }\end{array}$ \\
\hline
\end{tabular}

Table 4 Summary of loading conditions Source: Own Elaboration

Next, the boundary conditions (figure 6) and the results in maximum Von Mises stress (figure 7), due to the stress concentrator at the root junction point, and total displacement (figure 8) are shown for load hypothesis A: Flapwise. According to Castillo, it is acceptable to apply the Von Mises failure theory to composite materials as long as the material behaves more or less linear in the elastic zone in the stress-strain diagram. The glass fibre/Epoxy composite material has this kind of linear behaviour.

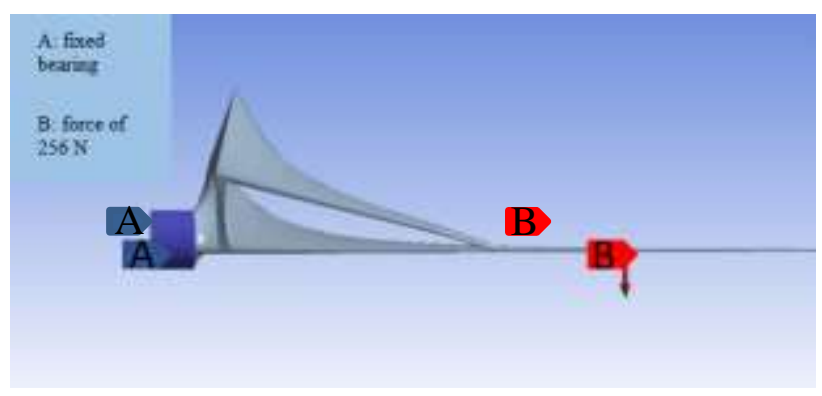

Figure 6 Blade boundary conditions Source: Own Elaboration

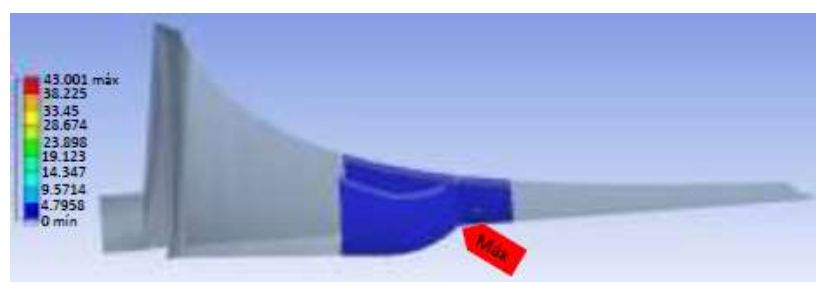

Figure 7 Von Mises maximum stress, on the top of the middle zone [MPa]

Source: Own Elaboration 


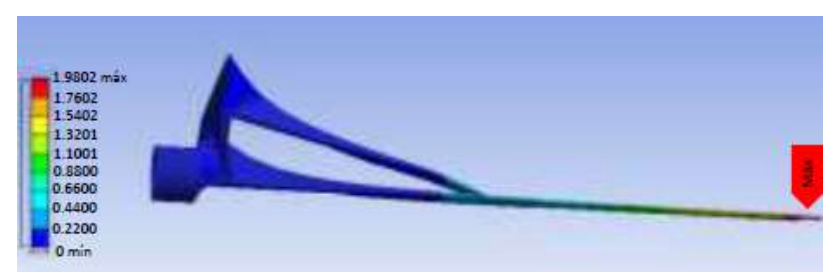

Figure 8 Total blade deflection [cm]

Source: Own Elaboration

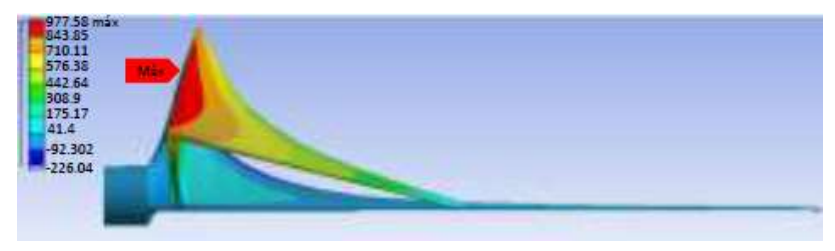

Figure 9 Directional blade deflection $[\mu \varepsilon]$ Soturce: Own Elaboration

Table 5 summarises the results obtained for total displacement, maximum Von Mises stress and directional displacement..

\begin{tabular}{|c|c|c|c|c|}
\hline \multicolumn{2}{|c|}{ Load assumptions } & $\begin{array}{c}\text { Total } \\
\text { displacement } \\
(\mathbf{m m})\end{array}$ & $\begin{array}{c}\text { Von } \\
\text { Mises } \\
\text { maximum } \\
\text { stress } \\
\text { (Mpa) }\end{array}$ & \multirow{2}{*}{$\begin{array}{l}\text { Maximum } \\
\text { directional } \\
\text { offset }(\mu \mathrm{m})\end{array}$} \\
\hline \multirow[t]{3}{*}{$\mathbf{A}$} & \multirow{3}{*}{$\begin{array}{l}\text { Normal } \\
\text { operation }\end{array}$} & $\mathrm{F}_{7 \mathrm{~B}}: 24.93$ & 35.27 & \\
\hline & & $\mathrm{M}_{\mathrm{xB}}: 43.00$ & 86.13 & 977.58 (eje z) \\
\hline & & $\mathrm{M}_{\mathrm{yB}}=2.59$ & 12.07 & $4.7282($ eje $x)$ \\
\hline $\mathbf{E}$ & $\begin{array}{l}\text { Maximum } \\
\text { rotational } \\
\text { speed }\end{array}$ & $\mathrm{F}_{\mathrm{zB}}: 127.48$ & 180.35 & $2170.5($ eje $z)$ \\
\hline $\mathbf{H}$ & $\begin{array}{l}\text { Extreme wind } \\
\text { load }\end{array}$ & $\mathrm{M}_{\mathrm{yB}}: 20.35$ & 94.69 & $18.876($ eje $x)$ \\
\hline
\end{tabular}

Table 5 Summary of the results obtained for the simulated load modes

Source: Own Elaboration

The results of the maximum Von Mises stresses for each layer and blade region are shown below

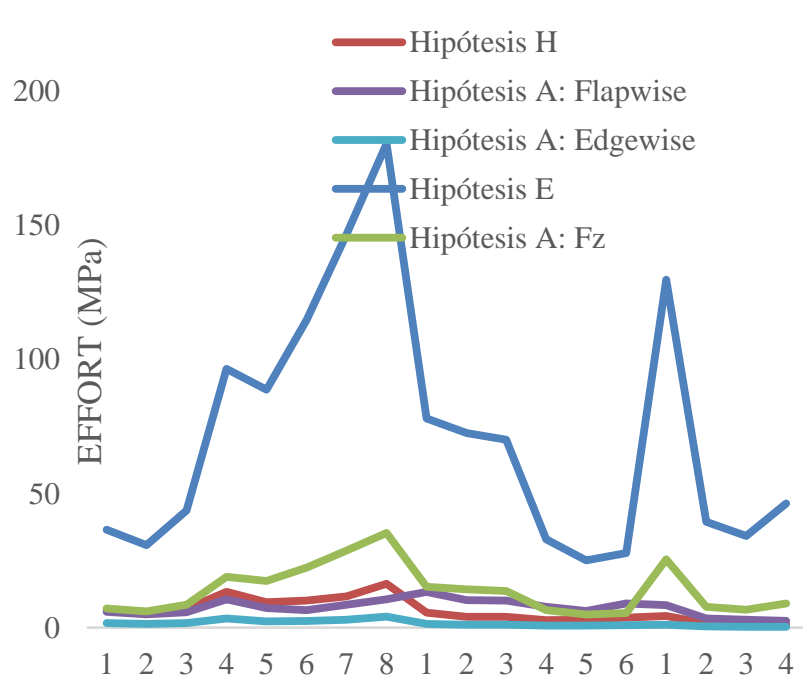

Graph 1 Stress distribution according to Von Mises failure theory, per blade for each loading scenario, blade socket [MPa]

Source: Own Elaboration

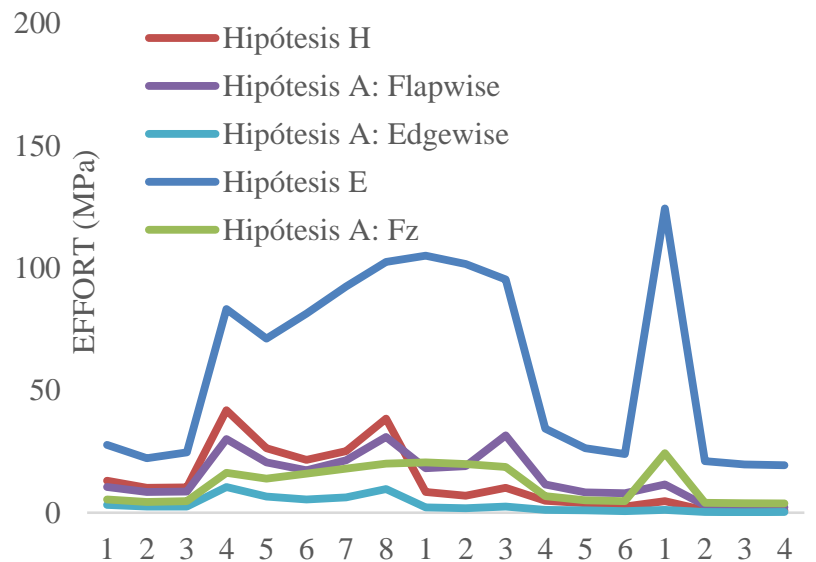

Graph 2 Stress distribution according to the Von-Misses failure theory, per blade for each of the loading hypotheses, blade top surface [MPa]

Source: Own Elaboration

As expected, the maximum stress values occur in the hypothesis of maximum rotational speed, close to the load application zone.

\section{Laboratory tests}

The methodology for carrying out the laboratory tests is as follows:

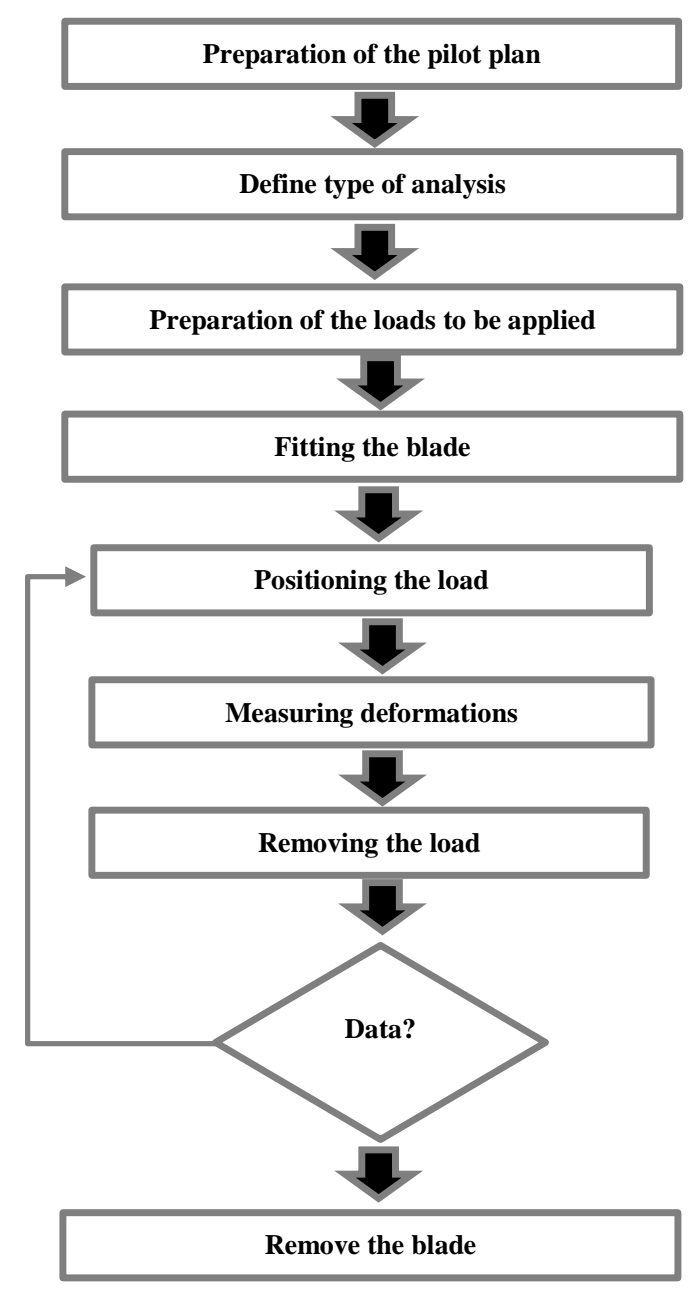

Figure 10 Methodology of laboratory tests Source: Own Elaboration

SANTIBAÑEZ-MALDONADO, Adrian, LÓPEZ-GARZA, Víctor, SORIANO-PEÑA, Juan Felipe and MARIN-TELLEZ, Paulina Proposal for structural testing of double root low capacity wind turbine blades based on the Iec 61400-2 Standard. Journal Innovative Design. 2021 
Strain gauges, which are basically a variable resistor, are attached to the surface of the blade for strain measurements.

The principle of operation of strain gauges is based on the piezoresistive effect of metals and semiconductors, whereby their resistivity varies according to the strain to which they are subjected, the material from which they are made and the design adopted. Thus, the change in electrical resistance will indicate a change in strain, which in turn is related to the forces acting on the instrumented element.

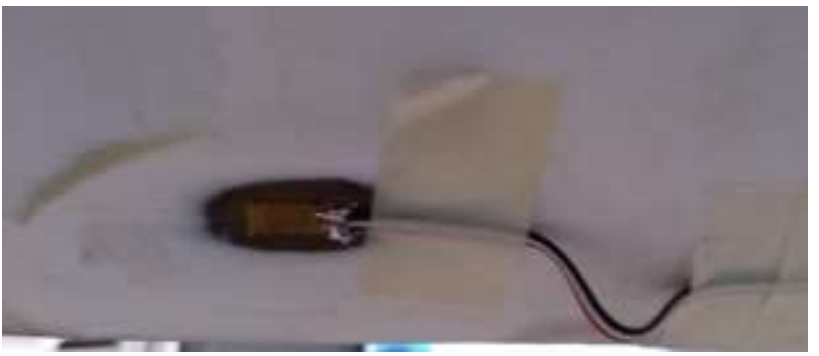

Figure 11 Calibre instalado en la hoja Source: Own Elaboration

For data collection, the gauges of the CEA-06-240UZ-120 model and a strain gauge and recorder of the P3 model were used.

The location of the gauges was chosen according to the results obtained in the numerical simulation. It should be noted that 2 of the 5 loading modes cannot be reproduced in the laboratory due to their complexity, so it is limited to 3 loading modes. The following table summarises the loading modes and their magnitudes, both in Newtons and in kilograms:

\begin{tabular}{|l|r|r|}
\hline Hypothesis & Charge (N) & Charge to be applied (kg) \\
\hline A: Flapwise & 256 & 26.1 \\
\hline A:Edgewise & 115 & 11.8 \\
\hline H: Edgewise & 459.1 & 46.8 \\
\hline
\end{tabular}

Table 6 Summary of loads to be applied in the laboratory Source: Own Elaboration

For the Flapwise tests, 4 gauges were installed, one on the root socket (A), $10 \mathrm{~cm}$ from the embedment, another on the socket of the double root $(\mathrm{B})$, at $1.85 \mathrm{~m}$, gauge $\mathrm{C}$ was installed on the socket of the double root at 1.85 $\mathrm{m}$ and finally gauge $\mathrm{D}$ was installed on the socket of the main vane at $2.62 \mathrm{~m}$.

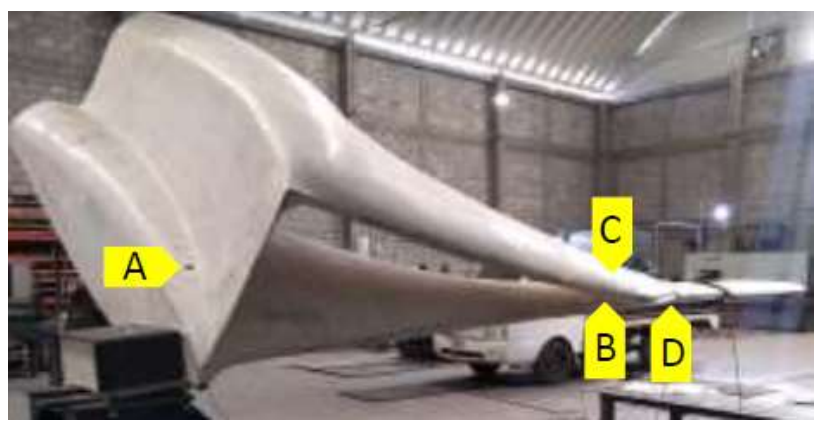

Figure 12 Flapwise testing gauges installed on blades Source: Own Elaboration

Thirty measurements were carried out for each loading mode, sensing each gauge, its temperature, humidity and ambient temperature. To avoid blade fatigue, it was decided to carry out the measurements over two days. The results obtained are shown below for the Flapwise mode:

\begin{tabular}{|l|r|r|r|r|}
\hline \multicolumn{5}{|l|}{ Load scenario A: Flapwise } \\
\hline $\begin{array}{l}\text { Measures of central tendency } \\
\text { central tendency and } \\
\text { dispersion }\end{array}$ & \multicolumn{1}{l}{ Gauge } \\
\cline { 2 - 6 } & A & B & C & D \\
\hline Media $(\mu \varepsilon)$ & 54.76 & 20.76 & -177.47 & -191.11 \\
\hline Fashion $(\mu \varepsilon)$ & 54 & 20 & -183 & -194 \\
\hline Standard deviation $(\mu \varepsilon)$ & 2.75 & 2.04 & 5.14 & 4.44 \\
\hline Coefficient of variation & 5.02 & 9.85 & 2.90 & 2.32 \\
\hline
\end{tabular}

Table 7 Results for day 1, 17 measurements were performed

Source: Own Elaboration

\begin{tabular}{|l|r|r|r|r|}
\hline \multicolumn{5}{|l|}{ Load scenario A: Flapwise } \\
\hline $\begin{array}{l}\text { Measures of central tendency } \\
\text { central tendency and } \\
\text { dispersion }\end{array}$ & \multicolumn{1}{|l|}{ Gauge } & A & C & D \\
\hline Media $(\mu \varepsilon)$ & 57.07 & 22.38 & -185.46 & -197.15 \\
\hline Fashion $(\mu \varepsilon)$ & 57 & 24 & -186 & -198 \\
\hline Standard deviation $(\mu \varepsilon)$ & 0.64 & 1.15 & 1.45 & 2.93 \\
\hline Coefficient of variation & 1.12 & 6.71 & 0.78 & 1.49 \\
\hline
\end{tabular}

Table 8 Results for day 2, 13 measurements were performed

Source: Own Elaboration

For the Edgewise tests, 4 gauges were installed, gauge $\mathrm{A}$ in the socket of the main root, $1.70 \mathrm{~m}$ from the embedment, gauge $\mathrm{B}$ at the same distance, $1.70 \mathrm{~m}$ in the socket of the main root, gauge $\mathrm{C}$ was installed in the socket of the main root at $2.40 \mathrm{~m}$ and finally gauge $\mathrm{D}$ was installed in the soffit of the double root at $2.40 \mathrm{~m}$ 


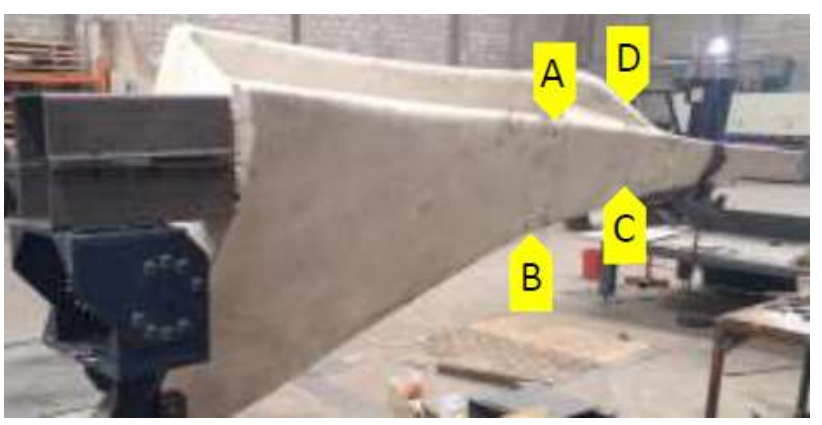

Figure 13 Blade mounted gauges for Edgewise tests Source: Own Elaboration

The results for the Edgewise loading mode for scenario A are shown below:

\begin{tabular}{|c|c|c|c|c|}
\hline \multicolumn{5}{|c|}{ Load scenario A: Edgewise } \\
\hline \multirow{2}{*}{$\begin{array}{l}\text { Measures of central tendency } \\
\text { central tendency and dispersion }\end{array}$} & \multicolumn{4}{|l|}{ Gauge } \\
\hline & A & B & $\mathrm{C}$ & $\mathrm{D}$ \\
\hline Media $(\mu \varepsilon)$ & -2.73 & 20.93 & 12.13 & 2.86 \\
\hline Fashion $(\mu \varepsilon)$ & -3 & 21 & 12 & 3 \\
\hline Standard deviation $(\mu \varepsilon)$ & 0.59 & 0.45 & 0.51 & 0.74 \\
\hline Coefficient of variation & 21.71 & 2.18 & 4.25 & 25.92 \\
\hline
\end{tabular}

Table 9 Results for day 1, 15 measurements were performed

Source: Own Elaboration

\begin{tabular}{|l|r|l|l|r|}
\hline \multicolumn{5}{|c|}{ Load scenario A: Edgewise } \\
\hline $\begin{array}{l}\text { Measures of central tendency } \\
\text { central tendency and } \\
\text { dispersion }\end{array}$ & Gauge \\
\cline { 2 - 6 } & A & B & C & D \\
\hline Media $(\mu \varepsilon)$ & -2.93 & 21.06 & 12.13 & 2.8 \\
\hline Fashion $(\mu \varepsilon)$ & -3 & 21 & 12 & 3 \\
\hline Standard deviation $(\mu \varepsilon)$ & 0.59 & 0.45 & 0.35 & 0.67 \\
\hline Coefficient of variation & 20.23 & 2.17 & 2.89 & 24.14 \\
\hline
\end{tabular}

Table 10 Results for day 2, 15 measurements were performed

Source: Own Elaboration

Finally, results are shown for the hypothesis $\mathrm{H}$ :

\begin{tabular}{|l|l|r|r|r|}
\hline \multicolumn{5}{|l|}{ Load scenario $\mathrm{H}$} \\
\hline $\begin{array}{l}\text { Measures of central tendency } \\
\text { central tendency and dispersion }\end{array}$ & \multicolumn{1}{l|}{ Gauge } \\
\cline { 2 - 6 } & A & \multicolumn{1}{l|}{ B } & \multicolumn{1}{l|}{ D } \\
\hline Media $(\mu \varepsilon)$ & -20.06 & 76.66 & 38.93 & -2.8 \\
\hline Fashion $(\mu \varepsilon)$ & -20 & 74 & 39 & -2 \\
\hline Standard deviation $(\mu \varepsilon)$ & 0.79 & 1.17 & 0.88 & 0.77 \\
\hline Coefficient of variation & 3.98 & 1.59 & 2.26 & 27.66 \\
\hline
\end{tabular}

Table 11 Results for day 1, 15 measurements were performed

Source: Own Elaboration

\begin{tabular}{|c|c|c|c|c|}
\hline \multicolumn{5}{|c|}{ Load scenario $\mathrm{H}$} \\
\hline \multirow{2}{*}{$\begin{array}{l}\text { Measures of central tendency } \\
\text { central tendency and dispersion }\end{array}$} & \multicolumn{4}{|c|}{ Gauge } \\
\hline & A & B & C & D \\
\hline Media $(\mu \varepsilon)$ & -19.33 & 72.73 & 38.86 & -2.53 \\
\hline Fashion $(\mu \varepsilon)$ & -19 & 74 & 39 & -2 \\
\hline Standard deviation $(\mu \varepsilon)$ & 1.34 & 1.53 & 0.74 & 1.18 \\
\hline Coefficient of variation & 6.95 & 2.10 & 1.91 & 46.86 \\
\hline
\end{tabular}

Table 12 Results for day 2, 15 measurements were performed

Source: Own Elaboration
Below is a comparison of the averages for each gage for each resgitrated loading mode:

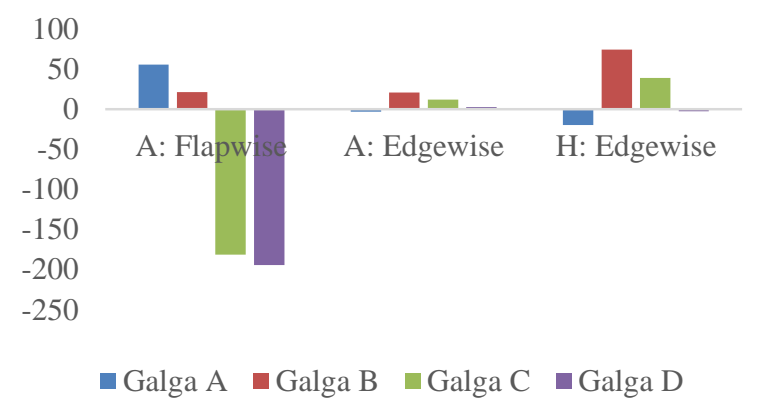

Graph 3 Recorded values for each load mode in micro deformations

Source: Own Elaboration

\section{Results}

For the loading mode of Hypothesis A: Flapwise, gauges $\mathrm{A}$ and $\mathrm{B}$, recorded tension measurements, as expected according to the numerical simulation, gauges $\mathrm{C}$ and $\mathrm{D}$ recorded compression measurements, according to the numerical simulation, gauge $\mathrm{C}$ should record tension measurements, which did not happen, gauge $\mathrm{D}$ is behaving as expected (in compression), both gauges showed the highest values due to the proximity to the load application point.

For the Edgewise modes of analysis, gauges $\mathrm{A}, \mathrm{B}$ and $\mathrm{C}$ had the same behaviour, both for hypothesis $\mathrm{A}$ and $\mathrm{H}$, gauge $\mathrm{D}$ was the only one that behaved differently, in tension in hypothesis $\mathrm{A}$ and in compression in hypothesis $\mathrm{H}$.

The coefficient of variation is low in general (except for a couple of occasions) which indicates that the tests were carried out homogeneously and that there is repeatability in the experiment. The highest standard deviation values were found for Hypothesis A: Flapwise, where the highest strain values were found, indicating that the higher the strain values, the greater the dispersion of the data and vice versa. Finally, the following graph shows an inversely proportional relationship between the values recorded by the gauge and the humidity in the environment, humidity being an important factor to consider when making the measurements. 


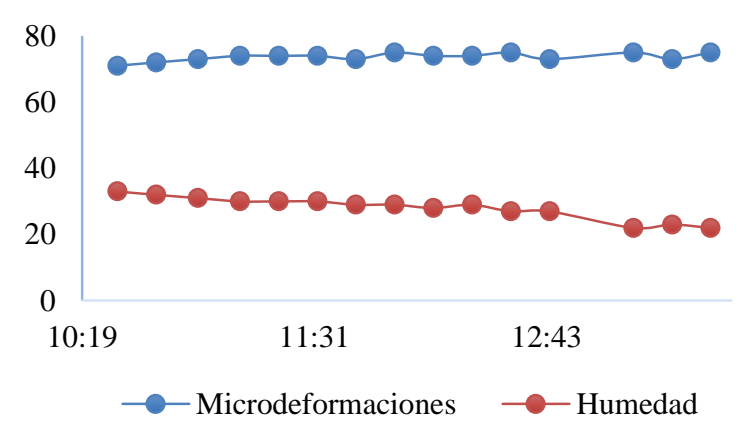

Gráfico 4 Correlation between ambient humidity and the value recorded in microdeformations for the $\mathrm{B}$ gauge of the H: Edgewise scenario

Source: Own Elaboration

\section{Acknowledgements}

To the Universidad Michoacana de San Nicolás de Hidalgo, to the Faculty of Mechanical Engineering and especially to the company NESTING CNC S.A. de C.V. and its staff for the facilities granted to develop this work. As well as to the National Council of Science and Technology for the scholarships granted to the postgraduate students.

\section{Conclusions}

As can be seen in this work, numerical simulation is a fundamental step prior to the design of turbine blades, as the results obtained are key to be able to carry out structural tests in the laboratory.

The highest deformation results measured in the laboratory by means of extensometry were obtained in Hypothesis A: Flapwise, as expected.

The values obtained in the laboratory indicate that the blade will work safely in operation, as the values obtained are far from the failure values. Therefore, we can conclude that the IEC 61400-2 standard can be perfectly applied to this type of double root blades following the methodology proposed for their structural analysis.

\section{References}

David Wood (2011). Small Wind turbines, Analysis, Design, and Application. SpringerVerlag London Limited.

Erick Pérez Juárez (2019). Construcción de una máquina de ensayo a fatiga para álabes de aerogeneradores de baja capacidad. UMSNH.
Esmeralda Castillo Sebastián (2016). Análisis de criterios de fallo para materiales compuestos, tesis, Universidad Politécnica de Valencia.

J. F. Manwell, J. G. MCgowan, A. L. Rogers (2009). Wind Energy Explained Theory, Design and Application, Second Edition. John Wiley \& Sons Ltd.

Jean-Daniel Pitteloud and Stefan Gsänger (2017). World Wind Energy Association. Small Wind World Report small wind report. WWEA, Bonn, Germany.

Monje, C. (2011). Metodología de la investigación cuantitativa y cualitativa guía didáctica, Neiva, Colombia: Universidad Surcolombiana.

Norma Europea EN 61400-2:2015 (2015). que a su vez adopta la Norma Internacional IEC 61400-2.

Paulina Marin Tellez (2020). Simulacion y pruebas de laboratorio de un aspa de turbina de viento de $600 \mathrm{~W}$ de acuerdo a la Norma IEC61400-2, UMSNH.

R.H. Barnes, E.V. Morozov, K. Shankar (2015). Improved Methodology for design of low wind speed specific wind turbine blades, Composite Structures 119, pg. 677-684.

SENSITEC S.A. de C.V. (2016). Extensometría Eléctrica.

Tony Burton, David Sharpe, Nick Jenkins, Ervin Bossanyi (2001). WIND ENERGY HANDBOOK, by John Wiley \& Sons, Ltd.

Victor López Garza et. al. (2018). Análisis preliminar estructural de un álabe de doble raíz de materiales compuestos para una turbina eólica de 3Kw. Revista de Aplicaciones de la Ingeniería. 2018. 5-17: 22-30.

Víctor López Garza (2020). Diseño y manufactura de álabes de turbinas de viento de eje horizontal de baja capacidad para bajas velocidades de viento, CIATEQ. 


\section{Annexes}

\section{Glossary}

$\mathrm{A}_{\text {proj }, \mathrm{B}}=$ Projected blade area

$\mathrm{B}=$ number of blades

$\mathrm{C}_{\mathrm{d}}=$ drag coefficient

$\mathrm{F}_{\mathrm{ZB}}=$ force on the blade at the root in the direction of the wingspan

$\mathrm{g}=$ acceleration of gravity

$\mathrm{m}_{\mathrm{B}}=$ mass of the shovel

$\mathrm{M}_{\mathrm{XB}}=$ bending moment at the blade root in direction $\mathrm{x}$

$\mathrm{M}_{\mathrm{yB}}=$ bending moment at the blade root in direction $\mathrm{y}$

$\mathrm{Q}_{\text {design }}=$ design axis torque

$\mathrm{R}=$ rotor radius

$\mathrm{R}_{\mathrm{cog}}=$ radial distance between the centre of gravity of the blade and the centre of the rotor.

$\mathrm{V}_{\mathrm{e} 50}=$ extreme value of speed in 50 years

$\rho=$ air density

$\lambda_{\text {design }}=$ blade tip speed ratio

$\Omega_{\mathrm{n}, \mathrm{design}}=$ rotor rotation speed

$\Omega_{\mathrm{n}, \mathrm{máx}}=$ maximum rotor rotational speed 